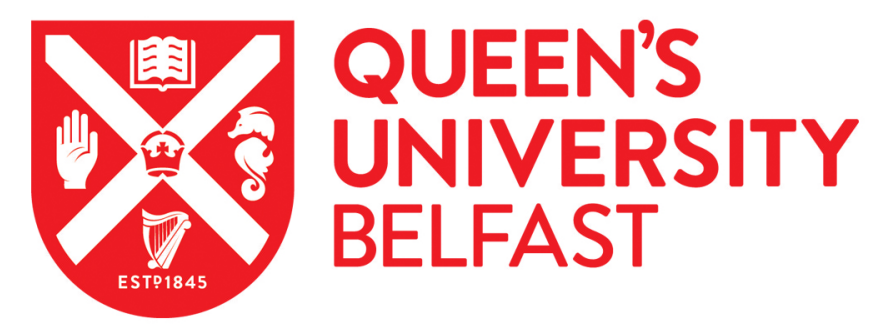

\title{
Digital pathology imaging offers more benefits than glass slides and microscopes
}

Houghton, J. P., Wilson, C. P., \& Dolaghan, M. J. (2016). Digital pathology imaging offers more benefits than glass slides and microscopes. British Medical Journal, 354. https://doi.org/10.1136/bmj.i3813

Published in:

British Medical Journal

Document Version:

Early version, also known as pre-print

Queen's University Belfast - Research Portal:

Link to publication record in Queen's University Belfast Research Portal

Publisher rights

Copyright 2016 The Authors

\section{General rights}

Copyright for the publications made accessible via the Queen's University Belfast Research Portal is retained by the author(s) and / or other copyright owners and it is a condition of accessing these publications that users recognise and abide by the legal requirements associated with these rights.

Take down policy

The Research Portal is Queen's institutional repository that provides access to Queen's research output. Every effort has been made to ensure that content in the Research Portal does not infringe any person's rights, or applicable UK laws. If you discover content in the Research Portal that you believe breaches copyright or violates any law, please contact openaccess@qub.ac.uk. 
Dear Editor,

This study involved the assessment of glass slides. The potential benefits of digital pathology images were briefly mentioned in this article.

We would like to make two points regarding digital pathology.

1. Internationally, there is a gradual acceptance among histopathologists that glass slides and microscopes will eventually be replaced by digital pathology images (like modern radiology) and this will greatly facilitate the ease of provision of an external second opinion $(1,2)$.

2. In current routine practice with traditional microscopes and glass slides, pathologists who work in small laboratories are usually described as "general pathologists". They report a very broad range of cases, but a relatively small volume of each and subspecialisation is limited to larger academic institutions. The implementation of digital pathology within a regional network of large academic laboratories and smaller district general hospital laboratories allows workload to be distributed differently and allows full subspecialistion irrespective of the size of the laboratory.

Dr Joseph P Houghton

Dr Carol P Wilson

Mr Michael J Dolaghan

Centre for Medical Education, Queen’s University Belfast

1. Gamechangers. On the cusp of a digital pathology revolution

Mr MJ Dolaghan, Dr JP Houghton, and Dr CP Wilson

Ulster Med J. 2016 Jan;85(1):58-9.

2. Implementation of large-scale routine diagnostics using whole slide imaging in Sweden: Digital pathology experiences 2006-2013

Thorstenson S, Molin J, Lundström C

J Pathol Inform 2014, 5:14 